\title{
成長期ラットにおける油脂の種類と摂取量の差異が 成熟後の脂肪摂取嗜好に及ぼす影響
}

\author{
中 嶋洋子*,1, 横山芽衣子 ${ }^{1}$ \\ 木 戸 誉 子 ${ }^{1}$, 下 田 淳 愛 ${ }^{1}$
}

(2006 年 8 月 1 日受付； 2006 年 11 月 20 日受理)

\begin{abstract}
要旨：若年者の魚嫌いが増加している原因を明らかにするため, 成長期に摂取した油脂の差異が成熟後の脂 質摂取嗜好に及ほすす影響を，低脂肪食飼料（LFD）と等カロリーになるよう調整したラードおよび魚油を添 加した高脂肪食飼料(HFD)を用いて調べた。 4 週齢の Fischer 344 系雄ラットを, LFD (LFD 群), lard HFD (lard HFD 群), fish oil HFD (fish oil HFD 群) で 8 週間飼育後, LFD 群は 3 群に, HFD 群は 2 群ずつに 分け，各群 1 群ずつを解剖し血漿と肝臓の脂質濃度を測定した。残りの LFD 群の 1 群と lard HFD 群には LFD と lard HFD を，他の LFD 群と fish oil HFD 群には LFD と fish oil HFD を同時に与えて 3 週間選択 摂取させた。全実験期間を通して，すべての群の摄取エネルギー量および体重に有意な差はみられなかった。 HFD 摂取割合は，LFD 群，HFD 群の両群とも，fish oil HFD が lard HFD に比べて有意に低かった。し たがって，LFD と HFD を選択摂取させた場合，fish oil HFD の嗜好性は lard HFD に比べて低いことが明 らかになった。
\end{abstract}

キーワード : 魚油摂取嗜好, 脂質選択摂取, 高脂肪食, 低脂肪食

わが国における肥満を中心とした生活習慣病増加の背 景には，食生活の変化がある。特に，若年世代の食事は 欧米化傾向にあり，畜産食品を中心とした高脂肪食へと 変化し, 動物性脂肪の摂取量が増加した ${ }^{1)}$ 。国民栄養調査 から食品の取り方をみると，従来から魚介類は日本人の 主要なタンパク質源として利用されてきたこともあり, 40 歳代以上では魚介類の摂取量が肉類を上回っている のに対し, 30 歳代以下では肉類の摂取量が高く魚を嫌う 傾向が強い。しかし, 肉類の脂肪は飽和脂肪酸とコレス テロールを多く含んでおり，過剩摂取は高脂血症や動脈 硬化などの生活習慣病のリスクを高める233) 一方, 魚油 に含まれる EPA や DHA などの多価不飽和脂肪酸に は, 血清脂質低下や抗血栓作用があり, 魚油の湶取は動 脈硬化症, 心筋梗塞, 脳梗塞などの予防効果を示し ${ }^{4-6)}$, また抗腫瘍作用や抗炎症作用も報告されている。

われわれは, 前報においで7, 成長期の仔ラットを標準 食飼料, 低脂肪食飼料掞よびラードを添加した高脂肪食 飼料で飼育し，成熟後低脂肪食飼料と高脂肪食飼料の選 択摂取を行わせ，成長期の脂質摄取量の差異が成熟期に おりる脂質摂取嗜好に及ぼす影響を調べた。選択摂取期 間の高脂肪食摄取割合は低脂肪食群が最も低く，標準食 群, 高脂肪食群の順であったが, 選択摂取期間を通して
いずれの群も $50 \%$ 以上を維持していた。したがって，成 長期の脂質摂取量の差異は成熟後の脂質摂取嗜好に影響 を与えたが，低脂肪食群や標準食群においても高脂肪食 摂取嗜好は強かった。

この場合，高脂肪食飼料は脂肪含量が高いと同時に工 ネルギー量も高いことから，次にセルロースを添加して 低脂肪食飼料と等カロリーに調整した高脂肪食飼料を用 いて同様の実験を行った ${ }^{8)}$ 。成熟期における等カロリー に調整した高脂肪食飼料摂取割合は低脂肪食群，高脂肪 食群のいずれにおいても大幅に低下したことから, ラッ 卜はエネルギー量が高いから高脂肪食飼料を好むのであ り等カロリーに調整した高脂肪食飼料では脂質の過剩な 摂取は起こらないだろうことが推測された。

武田らや今泉らは910), 数種の食用油脂を用いて, 油脂 を $1 \%$ 添加した飼料と添加しない飼料をマウスに選択摂 取させると，すべての食用油脂で油脂を添加した飼料が 添加しない飼料に対して有意に多く摄取されることを報 告している。しかし, 油脂を添加した飼料では, 飼料 $1 \mathrm{~g}$ あたりのエネルギー量が高くなるためにこのような結果 が得られたのかもしれないと推測される。

この点を明らかにするため, 本実験において, 成長期 における脂質摂取量の差異が成熟期における脂質摂取嗜

\footnotetext{
* 連絡者・別刷請求先 (E-mail: yokon@seitoku.ac.jp)

1 聖徳大学人文学部生活文化学科 (271-8555 千葉県松戸市岩瀬 550)
} 
好に及ぼす影響を，低脂肪食飼料と等カロリーになるよ う調整したラードおよび魚油を添加した高脂肪食飼料を 用いて調べ，若干の知見を得たので報告する。 EPA や DHA などの n-3 系多価不飽和脂肪酸を含む魚油は生活 習慣病予防効果が期待される油脂であるにもかかわら ず，若年者の魚嫌いが増加している原因についても併せ て考察したい。

\section{実 験 方 法}

\section{1. 飼 料 組 成}

実験に用いた飼料の組成は Table 1 に示した。飼料は AIN-93G に準じて調製した ${ }^{11)}$ 。すなわち，低脂肪食飼料 (LFD) はAIN-93G の脂肪量が $1 / 2$ になるように大豆油 を $3.5 \%$ に減らし，その分コーンスターチを増やした。高 脂肪食飼料 (HFD) は AIN-93G に2 倍量のラードまたは 魚油を添加しその分コーンスターチを減らし，さらに低 脂肪食飼料と等カロリーになるようにセルロースを添加 した。ラードを添加した HFD をラード高脂肪食飼料 (lard HFD)，魚油を添加した飼料を魚油高脂肪食飼料

Table 1 Composition of the experimental diets. ${ }^{1}$

\begin{tabular}{lcc}
\hline \hline Ingredient & Low-fat diet & High-fat diet \\
\hline Casein & 20.0 & 15.2 \\
L-Cystine & 0.3 & 0.23 \\
Corn starch & 56.45 & 29.6 \\
Sucrose & 10.0 & 7.6 \\
Soybean oil & 3.5 & 5.36 \\
Fat $^{4}$ & - & 10.6 \\
Cellulose $_{\text {Mineral mixture }}$ & 5.0 & 27.8 \\
Vitamin mixture $^{3}$ & 3.5 & 2.66 \\
Choline bitartrate $^{\text {tert-butylhydroquinone }}$ & 1.0 & 0.76 \\
\hline Energy (kcal/g) $_{\text {Fat energy ratio }}$ & 0.25 & 0.19 \\
Carbohydrate energy ratio & 0.0014 & 0.0014 \\
\hline \hline
\end{tabular}

${ }^{1}$ All ingredients are in grams per $100 \mathrm{~g}$ of diet. ${ }^{2,3}$ Mineral mixture and vitamin mixture were based on the AIN-93G formation. ${ }^{4}$ Fat: lard or fish oil. Each diet was freshly prepared each day to avoid oxidation of the lipids. (fish oil HFD) とした。Lard HFD は毎日調整した。 カゼイン， $\alpha$-コーンスターチ，ラード，セルロース， AIN-93G ミネラル混合, AIN-93G ビタミン混合は, オリ エンタル酵母工業(株)製を, L-シスチン, 大豆油, 重酒石 酸コリン， $t$-ブチルヒドロキノンは和光純薬工業(株)製 を用いた。魚油は日本水産(株)より入手した。

\section{2. 実験動物および飼育方法}

実験には，Fischer 344 系の雄ラット (4 週齢) 58 匹を 日本クレア(社)より購入して用いた。飼育は，室温 21 $\pm 2^{\circ} \mathrm{C}$ ，湿度約 $50 \%$ ，明暗サイクル 12 時間（7：0019：00）の飼育室で行った。ラットはステンレスケージ で個別に飼育し，飼料と水は自由に摂取させた。動物の 世話は毎日行い，体重と飼料摂取量を測定した。

実験計画は Figure 1 に示した。ラットは，購入後，平 均体重と体重のばらつきができるだけ同じになるよう に，LFD 群 26 匹，lard HFD 群 16 匹，fish oil HFD 群 16 匹の 3 群に分け，Table 1 に示したそれぞれの飼料で 8 週間飼育した（以下，実験食摂取期間とする）。実験食 摂取期間終了後, ラットは，平均体重と体重のばらつき ができるだけ同じになるように，LFD 群は 6 匹，10 匹， 10 匹の 3 群に, lard HFD 群と fish oil HFD 群は，それ ぞれ 6 匹と 10 匹の 2 群に分け, 各群 6 匹ずつを解剖し た。残りの LFD 群の 1 群と lard HFD 群には LFD と lard HFD 同時に与え (LFD : lard HFD 群), LFD 群の 他群と fish oil HFD 群には LFD と fish oil HFD を同時 に与えて (LFD : fish oil HFD 群) 3 週間選択摂取させ た（以下，選択摂取期間とする)。実験食摂取期間と選択 捸取期間中，fish oil HFD は毎日調整した飼料に取り替 え，それぞれの飼料摂取量と体重を測定した。実験終了 後, ラットはエーテル麻酔下に心臓より採血し, 肝臓と 脂肪組織を採取し重量を測定した。血液は，1,500×gで 30 分間遠心分離した後, 血漿を得た。血漿および肝臓は 分析時までー $85^{\circ} \mathrm{C}$ で保存した。

動物実験は，聖徳大学動物実験指針に基づき，「実験動 物の飼育および保管に関する基準（総理府告示第 6 号）」 を遵守して行った。

\section{3. 血清および肝臓脂質の測定}

肝臓の脂質は Folch et al. ${ }^{12)}$ の方法に準じて，クロロ

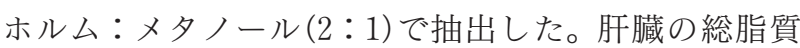
は, 得られた肝臓抽出液の一部を用い, 重量法で測定し

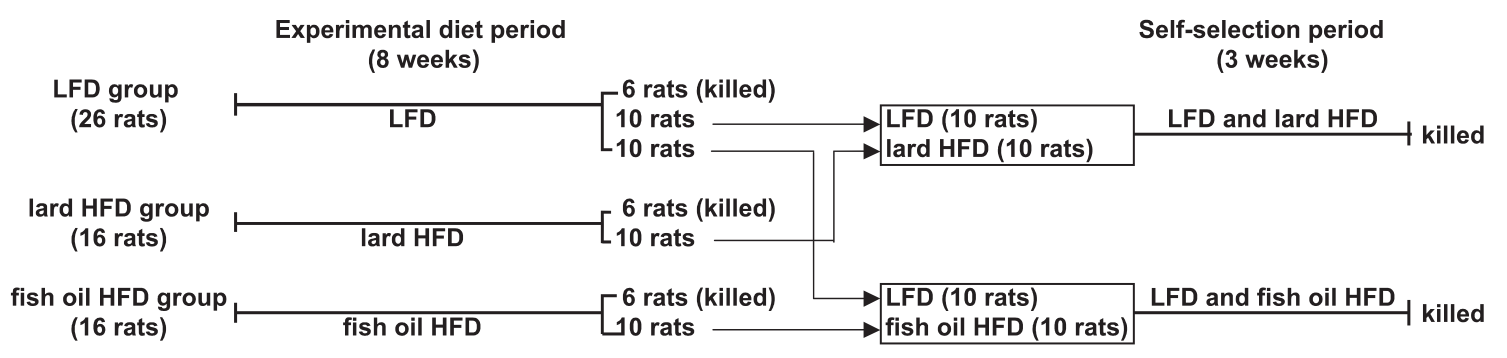

Figure 1 Design of experiment. 
た。残りの肝藏抽出液は，コール酸ナトリウムを加え減 圧下で乾固した後，イオン交換水に溶解し脂質測定溶液 とした。血漿および肝臓のトリアシルグリセロールの測 定にはトリグリセリド E-テスト(和光純薬工業(株)製) を用い, 総コレステロールの測定にはコレステロール Eテスト（和光純薬工業(株)製）を用いた。

\section{4. 統 計処理}

データはANOVA 法で統計処理を行い, 多群間の比 較にはScheffeの多重比較検定を，2群間の比較には Student's $t$-test を用いた。Figure 2 と 3 の経時変化の比 較は二元配置分散分析を行った。ソフトはエクセル統計 2004 (Microsoft 社) を用いた。データは，平均土標準偏

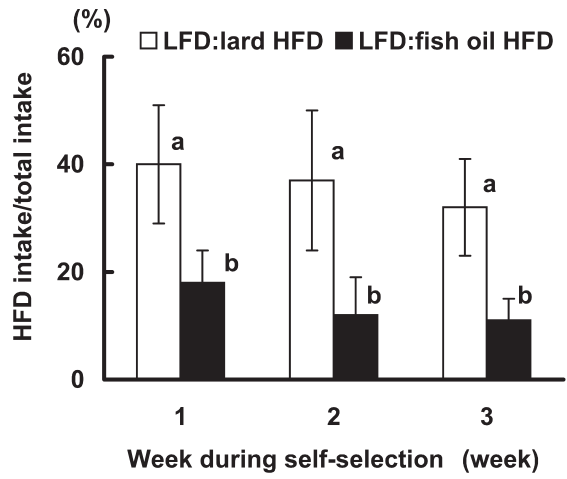

Figure 2 Ratio of high-fat diet intake/total intake of low-fat diet group during self-selection period for 3 weeks after being fed low-fat diet for 8 weeks. Values are expressed as mean $\pm \mathrm{SD}(n=10)$. Values not sharing a common superscript letters are significantly different at $p<0.05$. Statistical interactions as derived from analysis of variance: $p<0.05$ for diet, $p=0.653$ for week during self-selection and $p=138$ for diet $\times$ week during self-selection.
差（mean士SD）で示した。いずれの場合も $p<0.05$ で 有意差ありと判定した。

\section{実 験 結 果}

\section{1. 飼料摂取量亡体重変化}

実験食摂取期間の LFD 群，lard HFD 群および fish oil HFD 群の 3 群間の総飼料捸取量，および選択摂取期 間の LFD 群 2 群と HFD 群 2 群の 4 群間の総飼料摂取 量には，いずれも有意な差はみられなかった（Table 2)。したがって，実験食摂取期間の 3 群間の体重，およ び選択摂取期間の 4 群間の体重にもいずれも有意な差は

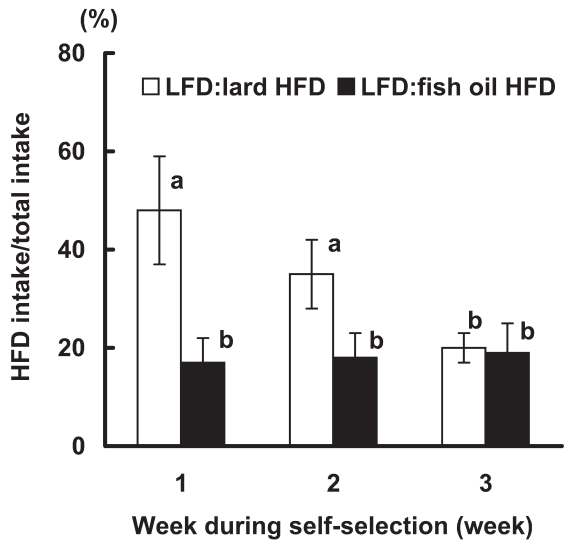

Figure 3 Ratio of high-fat diet intake/total intake of high-fat diet group during self-selection period for 3 weeks after being fed high-fat diet containing lard or fish oil for 8 weeks. Values are expressed as mean \pm SD $(n=10)$. Values not sharing a common superscript letters are significantly different at $p<$ 0.05 . Statistical interactions as derived from analysis of variance: $p<0.05$ for diet, week during selfselection and diet $\times$ week during self-selection.

Table 2 Effect of dietary fat on food intake during dietary treatment period for 8 weeks and ratio of high-fat diet intake to total intake during self-selection period for 3 weeks.

\begin{tabular}{|c|c|c|c|c|}
\hline \multicolumn{5}{|c|}{ Dietary treatment period for 8 weeks } \\
\hline Group & $\begin{array}{c}\text { Age } \\
\text { (week) }\end{array}$ & $n$ & $\begin{array}{l}\text { Total food intake } \\
\text { (g) }\end{array}$ & \\
\hline Low-fat diet & 12 & 26 & $671 \pm 40$ & \\
\hline Lard high-fat diet & 12 & 16 & $714 \pm 41$ & \\
\hline Fish oil high-fat diet & 12 & 16 & $710 \pm 49$ & \\
\hline \multicolumn{5}{|c|}{ Self-selection period for 3 weeks } \\
\hline Group & $\begin{array}{c}\text { Age } \\
\text { (week) }\end{array}$ & $n$ & $\begin{array}{l}\text { Total food intake } \\
\text { (g) }\end{array}$ & $\begin{array}{c}\text { HFD intake/ } \\
\text { total intake (\%) }\end{array}$ \\
\hline \multicolumn{5}{|l|}{ Low-fat diet } \\
\hline LFD : lard HFD & 15 & 10 & $352 \pm 23$ & $34.8 \pm 14.0^{\mathrm{a}}$ \\
\hline LFD : fish oil HFD & 15 & 10 & $344 \pm 41$ & $12.7 \pm 4.9^{\mathrm{b}}$ \\
\hline \multicolumn{5}{|l|}{ High-fat diet } \\
\hline LFD : lard HFD & 15 & 10 & $363 \pm 22$ & $32.6 \pm 7.1^{\mathrm{a}}$ \\
\hline LFD : fish oil HFD & 15 & 10 & $373 \pm 17$ & $15.7 \pm 5.4^{\mathrm{b}}$ \\
\hline
\end{tabular}

Values represent means \pm SD. Within a column, values not sharing a common superscript letter are significantly different at $p<0.05$. 
Table 3 Effect of dietary fat on body, liver and fat tissue weights, and concentration of serum and hepatic lipids after dietary treatment for 8 weeks.

\begin{tabular}{|c|c|c|c|}
\hline \multirow{2}{*}{ Group } & \multirow{2}{*}{ Low-fat diet } & \multicolumn{2}{|c|}{ High-fat diet } \\
\hline & & Lard HFD & Fish oil HFD \\
\hline Body weight $(\mathrm{g})$ & $228 \pm 19$ & $227 \pm 14$ & $235 \pm 13$ \\
\hline Liver weight $(\mathrm{g} / 100 \mathrm{~g})$ & $3.88 \pm 0.31^{\mathrm{a}}$ & $3.31 \pm 0.19^{b}$ & $3.64 \pm 0.19^{\mathrm{ab}}$ \\
\hline \multicolumn{4}{|l|}{ Fat tissue weight } \\
\hline Perirenal (g/100 g) & $1.12 \pm 0.17^{\mathrm{a}}$ & $0.98 \pm 0.12^{\mathrm{a}}$ & $0.80 \pm 0.04^{\mathrm{b}}$ \\
\hline Epididymal (g/100 g) & $1.97 \pm 0.24^{\mathrm{a}}$ & $1.64 \pm 0.24^{\mathrm{ab}}$ & $1.42 \pm 0.14^{\mathrm{b}}$ \\
\hline \multicolumn{4}{|l|}{ Plasma } \\
\hline Triacylglycerides (mg/dL) & $135.5 \pm 21.7^{\mathrm{a}}$ & $126.6 \pm 20.0^{\mathrm{a}}$ & $71.9 \pm 16.9^{\mathrm{b}}$ \\
\hline Total cholesterol (mg/dL) & $80.3 \pm 6.3^{\mathrm{a}}$ & $64.2 \pm 8.4^{\mathrm{b}}$ & $41.1 \pm 2.5^{\mathrm{c}}$ \\
\hline \multicolumn{4}{|l|}{ Liver } \\
\hline Total lipids (mg/g) & $49.4 \pm 1.2^{\mathrm{a}}$ & $66.1 \pm 7.9^{b}$ & $80.6 \pm 8.7^{\mathrm{b}}$ \\
\hline Triacylglycerides $(\mathrm{mg} / \mathrm{g})$ & $7.7 \pm 1.0^{\mathrm{a}}$ & $14.5 \pm 4.0^{\mathrm{b}}$ & $13.6 \pm 3.3^{\mathrm{b}}$ \\
\hline Total cholesterol (mg/g) & $1.34 \pm 0.08^{\mathrm{a}}$ & $1.79 \pm 0.20^{\mathrm{b}}$ & $2.69 \pm 0.29^{c}$ \\
\hline
\end{tabular}

Values represent means \pm SD. $n=6$. Within a row, values not sharing a common superscript letter are significantly different at $p<0.05$.

Table 4 Effect of dietary fat level on body, liver and fat tissue weights, and concentration of serum and hepatic lipids after self-selection for 3 weeks.

\begin{tabular}{|c|c|c|c|c|}
\hline \multirow{2}{*}{ Group } & \multicolumn{2}{|c|}{ Low-fat diet } & \multicolumn{2}{|c|}{ High-fat diet } \\
\hline & LFD: lard HFD & FD: fish oil HFD & LFD: lard HFD & LFD: fish oil HFD \\
\hline Body weight $(\mathrm{g})$ & $277 \pm 11$ & $273 \pm 14$ & $279 \pm 15$ & $294 \pm 13$ \\
\hline Liver weight $(\mathrm{g} / 100 \mathrm{~g})$ & $3.49 \pm 0.10$ & $3.58 \pm 0.16$ & $3.56 \pm 0.12$ & $3.44 \pm 0.11$ \\
\hline \multicolumn{5}{|l|}{ Fat tissue weight } \\
\hline Perirenal $(\mathrm{g} / 100 \mathrm{~g})$ & $1.50 \pm 0.18^{\mathrm{a}}$ & $1.21 \pm 0.07^{\mathrm{b}}$ & $1.31 \pm 0.09^{\mathrm{ab}}$ & $1.22 \pm 0.08^{\mathrm{b}}$ \\
\hline Epididymal (g/100 g) & $2.18 \pm 0.25$ & $2.02 \pm 0.15$ & $2.21 \pm 0.24$ & $2.10 \pm 0.29$ \\
\hline \multicolumn{5}{|l|}{ Plasma } \\
\hline Triacylglycerides $(\mathrm{mg} / \mathrm{dL})$ & $195.3 \pm 47.3^{\mathrm{ab}}$ & $158.0 \pm 25.3^{\mathrm{b}}$ & $292.4 \pm 42.5^{\mathrm{a}}$ & $154.1 \pm 39.6^{\mathrm{b}}$ \\
\hline Total cholesterol (mg/dL) & $78.3 \pm 8.1^{\mathrm{a}}$ & $76.0 \pm 5.1^{\mathrm{a}}$ & $81.2 \pm 8.7^{\mathrm{a}}$ & $66.8 \pm 2.29^{\mathrm{b}}$ \\
\hline \multicolumn{5}{|l|}{ Liver } \\
\hline Total lipids (mg/g) & $49.7 \pm 5.5$ & $51.4 \pm 3.0$ & $52.0 \pm 4.1$ & $51.4 \pm 3.0$ \\
\hline Triacylglycerides $(\mathrm{mg} / \mathrm{g})$ & $8.50 \pm 2.1$ & $8.57 \pm 2.0$ & $9.36 \pm 0.65$ & $10.1 \pm 0.78$ \\
\hline Total cholesterol (mg/g) & $1.11 \pm 0.12$ & $1.10 \pm 0.10$ & $1.09 \pm 0.03$ & $1.16 \pm 0.09$ \\
\hline
\end{tabular}

Values represent means \pm SD. $n=10$. Within a row, values not sharing a common superscript letter are significantly different at $p<0.05$.

みられなかった（Table 3，4）。しかし，選択摂取期間 の高脂肪食飼料摂取割合 [高脂肪食飼料摂取量 $(\mathrm{g}) /$ 総摂 取量 $(\mathrm{g})$ ]は，LFD 群および HFD 群ともに，LFD：fish oil HFD 群が LFD : lard HFD 群に比べて有意に低か った $(p<0.05)$ (Table 2)。

選択摂取期間中の, LFD 群の高脂肪食飼料摂取割合の 経時変化を Figure 2 に示した。3 週間を通して高脂肪食 摂取割合は LFD：fish oil HFD 群が LFD : lard HFD 摂取群に比べて有意に低かった（

HFD 群の高脂肪食飼料摂取割合の経時変化は Figure 3 に示した。選択摂取 1 週目の LFD : lard HFD 群の高 脂肪食摂取割合は, LFD：fish oil HFD 群の約 3 倍と高 かったが，急速に低下して 3 週目には約 $20 \%$ となり， LFD : fish oil HFD 群の高脂肪食摂取割合との間に差が
みられなくなった。LFD：fish oil HFD 群の高脂肪食摂 取割合は，3 週間を通して有意な差はみられなかった。

2. 実験食摂取期間後の肝臓および脂肪組織重量, 血 漿および肝臓脂質濃度に及ぼす油脂の影響

実験食投与期間後の体重当たり肝臓重量は, LFD 群が 最も高く， lard HFD 群が最も低く両群間に有意な差が みられた $(p<0.05)$ (Table 3)。体重当たり後腹壁脂肪 組織重量および副睪丸周辺脂肪組織重量は, LFD 群が最 も高く， lard HFD 群， fish oil HFD 群の順に低下した $(p<0.05)$ 。

血漿トリアシルグリセロール濃度は fish oil HFD 群 が最も低く，他の 2 群との間に有意な差がみられた $(p<$ $0.05)$ 。血漿総コレステロール濃度は fish oil HFD 群が最 も低く, lard HFD 群, LFD 群の順に高かった $(p<0.05)$ 。 
また，肝臓の総脂質およびトリアシルグリセロール濃度 は，低脂肪食群が最も低く他の 2 群との間に有意な差が みられた $(p<0.05)$ 。肝臓総コレステロール濃度は LFD 群が最も低く, lard HFD 群, fish oil HFD 群の順に高 くなった。

\section{3. 実験食摂取期間後の肝臓および脂肪組織重量, 血 漿および肝臓脂質濃度に及ぼす油脂の影響}

選択摂取期間後の肝臓重量および肝蔵の脂質濃度に は，いずれも 4 群間で有意な差はみられなかった(Table 4)。後腹壁脂肪重量は, LFD 群では LFD : lard HFD 群 が LFD：fish oil HFD 群に比べて有意に高かったが, HFD 群では LFD：lard HFD 群と LFD： fish oil HFD 群間に有意な差はみられなかった $(p<0.05)$ 。副睪丸周辺 脂肪組織重には，4 群間で有意な差はみられなかった。

血漿トリアシルグリセロールおよび総コレステロール 濃度は，LFD 群では LFD : lard HFD 群と LFD : fish oil HFD 群間に有意な差はみられなかったが，HFD 群 では LFD： lard HFD 群が LFD： fish oil HFD 群間に 比べて有意に高かった $(p<0.05)$ 。

\section{考察}

油脂は食品においしさを与える重要な要因であり，油 脂含量の高い食品が好まれることは経験的に知られてい る。しかし，われわれは前報において，ラードを添加し た HFD の高い暏好性は，セルロースを加えて LFD と等 カロリーに調整すると低下することを報告した ${ }^{8)}$ 。魚油 は EPA や DHA などの n-3 系脂肪酸を豊富に含み, これ らの脂肪酸は種々の生活習慣病の予防効果を示すことが 知られているにもかかわらず，魚嫌いの子どもが増えて いることから, 本研究では, 魚油の嗜好性についてラー ドとの比較を行った。

成長期に大豆油のみを摂取した LFD 群を成熟後 2 群 に分け，1群は LFD と lard HFD の, 他群は LFD と fish oil HFD の選択摂取を行わせると，3 週間を通して lard HFD の摂取割合は fish oil HFD の摂取割合よりも 約 2.7 倍高かった（Table 2, Figure 2)。したがって， 成長期に摂取経験がない場合には，魚油の嗜好性はラー ドに比べて低いことがわかった。

成長期に lard HFD または fish oil HFD を摂取した ラットに，それぞれ LFD と lard HFD，LFD と fish oil HFD の選択摂取を行わせると, 選択摂取直後は LFD : lard HFD 群の HFD 摂取割合は LFD : fish oil HFD 群 に比べて約 3 倍高かったが, LFD : lard HFD 群の HFD 摂取割合は急速に低下し，3 週間目にはLFD：fish oil $\mathrm{HFD}$ 群の HFD 摂取割合との間に有意な差がみられな くなった (Figure 3)。前報において ${ }^{8)}$, 高脂肪食飼料の 嗜好性は高く低脂肪食飼料との選択摂取により $80 \%$ 前 後の高率で高脂肪食飼料を摂取するが，等カロリーにな るよう調整した高脂肪食飼の嗜好性は低く高脂肪食飼料 摂取割合は選択摂取直後 55\%から 20\%に低下すること
を報告したが，本研究においても同様の結果が得られ た。Lardの嗜好性は fish oil よりも高いため，選択摂取 直後 LFD：lard HFD 群の HFD 摂取割合は LFD : fish oil HFD 群に比べて高かったのではないかと推測され た。

3 週目の両群の HFD 摂取割合は約 $20 \%$ ありりこの 值からラットが攝取した脂肪量を計算すると $7.0 \mathrm{~g} / 100$ $\mathrm{g}$ 飼料となるように摂取したことになる。この值は AIN93G の脂質量と同じであった。したがって, LFD と 等カロリーになるよう調整した lard HFD と LFD を選 択摂取させると選択摂取直後は lard HFD の摂取割合は 高かったが，選択摂取 3 週目には適正な量の脂質を摂取 するようになった。しかし, LFD : fish oil HFD 群の fish oil HFD 摂取割合は，選択摂取期間を通して約 20\%を維 持しており，LFD：fish oil HFD 群は選択攝取期間を通 して $7.0 \mathrm{~g} / 100 \mathrm{~g}$ 飼料となるように, 適切と考えられる脂 質量を摂取していた。

さらに，選択摂取期間に低脂肪食群の LFD：fish oil HFD 群が摂取した脂質摂取量を計算すると $5.8 \mathrm{~g} / 100 \mathrm{~g}$ 飼料であり，この值は AIN93G の脂質量に比べれば低か ったが, AIN93M の脂質量 $4 \mathrm{~g} / 100 \mathrm{~g}$ よりも高かった。 以上の結果から， fish oil HFD の嗜好性は lard HFD に 比べて低かったが, fish oil HFD 群においてもラットは 必要なだけの脂質量は摂取しており，さらに成長期に摂 取経験があれば啇正な脂質量で魚油を摂取することが明 らかになった。

実験食攝取期間の LFD 群，lard HFD 群および fish oil HFD 群の飼料攝取量には有意な差はみられず，3 群 のラットは等カロリーになるように飼料を捸取してお り，各群間の体重に有意な差はみられなかった（Table 2，3）。しかし，実験食摂取期間後の体重あたり肝藏重量 は LFD 群が最も高く lard HFD 群が最も低く, 肝蔵の 総脂質とトリアシルグリセリド濃度は LFD 群が他の 2 群に比べて有意に低かった(Table 3)。この原因として, LFD では脂肪を減らした分糖質を増やし，HFD では脂 肪を増やした分糖質を減らしたため，LFDの糖質含量 はHFDに比べて高くなっていることが考えられた (Table 1)。今回は肝蔵のグリコーゲン濃度は測定して いないが，摂取した糖質は肝臓に運ばれグリコーゲンと して貯蔵されるため，LFD 群では肝臓グリコーゲン濃 度が高まっていることが予測され，肝臓重量が増加した 原因ではないかと推測された ${ }^{13)}$ 。したがって選択摂取期 間後には, LFD 群と HFD 群の肝臓重量および肝藏の脂 質濃度に有意な差はみられなくなった（Table 4）。

血漿トリアシルグリセロール濃度は，食慨条件により 大きく変動し，また加齢とともに増加するが7)14)15), 本研 究においても LFD 群, lard HFD 群ともに血漿トリアシ ルグリセロール濃度は fish oil HFD 群に比べて高かっ た。 lard HFD を用いて実験を行った前報では7)，LFD 群と HFD 群の他に標準食飼料（AIN-93G）を摂取した 
群を設けたが，血漿トリアシルグリセロール濃度は標準 食群が最も低く，LFD 群，HFD 群ともに標準食群に比 べて高かった。この原因として HFD 群では長期間にわ たる飽和脂肪酸の多量摂取による血漿卜リアシルグリ セロール濃度の上昇と脂肪組織への蓄積が考えられ た ${ }^{714-16)}$ 。一方，LFD 群では多量に摂取した糖質はおも に肝臓で脂肪酸に合成されるが，肝蔵で合成されたトリ アシルグリセロールはVLDLに合成されて血中に運び

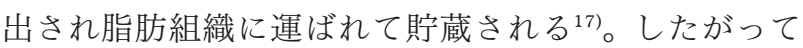
LFD 群においても血墏のトリアシルグリセロール濃度 は高く，体重当たりの脂肪組織量は高かった (Table 3)。 前報においては，肝臓の脂肪酸合成酵素 (EC 2.1.3.85) と 脂肪酸合成に必要な NADPH の合成に関与するグル コース-6-リン酸脱水素酵素（EC 1.1.1.49）の活性を測定 したが，LFD 群のこれらの酵素活性は標準食群や HFD 群に比べて有意に高かった は, 肝臓の脂肪酸合成に関与する一連の酵素系は誘導さ れて上昇し, 脂肪酸合成が充進するために消費されずに 残った糖質の大部分は体内でトリアシルグリセロールに 変換されるという多数の報告がある ${ }^{18) 19) 。 ~}$

また, fish oil HFD 群の脂肪組織重量および血漿卜リ アシルグリセリドと総コレステロール濃度は他の 2 群に 比べて有意に低かった（Table 3)。近年，脂肪酸に結合 することができる核内受容体の存在と作用が解明されて きているが，魚油に含まれる多価不飽和脂肪酸は，肝臓 や骨格筋で脂肪酸の $\beta$-酸化に関与する酵素をコードし ている遺伝子の発現を増加させ，また解糖系，脂肪酸合 成系，コレステロール合成系の酵素をコードしている遺 伝子の発現を抑制していることが報告されてい $3^{20-23)}$ 。多価不飽和脂肪酸のこれらの作用は, 脂質合成 の減少と脂質酸化の増加を意味しており, fish oil HFD 群での脂肪組織量の減少と血漿脂質濃度の低下を説明で きる。また，選択摂取期間後においても，HFD群の LFD : fish oil HFD 群の血漿トリアシルグリセリド濃度 および血漿総コレステロール濃度は LFD : lard HFD 群に比べて有意に低かった（Table 4)。

ヒトにおいては，胃の拡張が充満という副交感神経刺 激を発することにより一定量の食物を摂取する傾向があ ると報告されており ${ }^{24) 25)}$, 一般に, 高脂肪食や食物繊維含 量の低い食事では食事容量が低くなるため, エネルギー の過剩摂取を促進するとされている ${ }^{26)}$ 。しかし，本研究 において，実験に用いた lard HFD および fish oil HFD はともにLFD と等カロリーになるように調整したた め，実験食投与期間および選択摂取期間を通して，すべ ての群間の摂取エネルギー量に有意な差はみられず，し たがって体重にも有意な差はみられなかった（Table 2, 3)。しかし, 本研究に用いた lard HFD と fish oil HFD は LFDの 5 倍量のセルロースを含んでおり，このため lard HFD 群と lard HFD 群の血漿総コレステロール濃 度は LFD 群に比べて低下したのではないかと推測され
た（Table 3)。また，肝臓の総コレステロール濃度は， 血漿濃度とは逆に LFD 群が最も低く, 次いで lard HFD 群, fish oil HFD 群の順に高くなったが, HFD 群では血 漿濃度の低下から代償的に肝臓での合成が高まっている 可能性が考えられた。しかし，HFD 群は，実験食摂取期 間中大量のセルロースを摂取したにも関わらず，下痢な どの害作用は全く観察されず，体重は摂取エネルギー量 に比例して順調に増加した。

成長期に，ラードも魚油も摂取経験のない LFD 群お よび摂取経験のある HFD 群のいずれの群においても， 選択摂取後 1 週目， 2 週目の魚油の嗜好性はラードに比 べて低かった（Figure 2，3）。近年，食生活の欧米化に 伴い魚嫌いの子どもが増えているが，ヒトにおいてもラ ードに比べて魚油の嗜好性が低い可能性が考えられる。 本研究結果がヒトにも適応するかどうかさらなる研究が 待たれるところである。

8 週間の選択摂取期間に, fish oil HFD 群の飼料摂取 量および体重は他の 2 群と差はないにもかかわらず，脂 肪組織重量および血漿脂質濃度が最も低かったことか ら，特に生活習慣病の予防に役立つ油脂であることは本 研究においても明らかであり，魚油の嗜好性に関する研 究は重要であると考えられる。食物に対する嗜好性は食 文化に依存する面があり，幼い頃から食べ慣れた味はお いしいと感じるのが一般的である。魚油に特有の脂肪酸 である EPA やDHA に関する機能性についての研究は 精力的に進められているが，同時に，嗜好性に関する研 究も必要と考える。

\section{文献}

1）健康・栄養情報研究会編（2002）国民栄養の現状 一平成 14 年国民栄養調査結果一，p. 28-47. 第一出 版, 東京.

2) $\mathrm{Hu} F B$, Stampfer MJ, Rimm E, Ascherio A, Rosner BA, Spiegeiman D, Willet WC (1999) Dietary fat and coronary heart disease: a comparison of approaches for adjusting for total energy intake and modeling repeated dietary measurements. Am J Epidemiol 149: 531-40.

3) Bray GA, Popkin BM (1998) Dietary fat intake does affect obesity! Am J Clin Nutr 68: 1157-73.

4) Marckmann P, Gronbaek M (1999) Fish consumption and coronary heart disease mortality. A systematic review of prospective cohort studies. Eur J Clin Nutr 53: 585-90.

5) Thorngren M, Gustafson A (1981) Effect of 11week increase in dietary eicosapentanoic acid on bleeding time, lipids and platelet aggregation. Lancet 2: 1190-3.

6) Holmes MD, Hunter DJ, Colditz GA (1999) Association of dietary intake of fat and fatty acid with risk of breast cancer. JAMA 281: 914-20.

7）中嶋洋子，野本裕子（2005）成長期ラットにおける 脂肪摂取量の差異が成熟後の脂肪摂取嗜好に及ぼす 影響. 日本栄養・食糧学会誌 58, 59-64.

8）中嶋洋子（2006）成長期ラットの脂肪およびセル 
ロース摂取量の差異が成熟後の脂肪摂取嗜好に及ぼ す影響. 食糧学会誌 59, 297-304 (2006).

9) Takeda M, Imaizumi M, Fushiki T (2000) Preference for vegetable oil in the two-bottle choice test in mice. Life Sci 67: 197-204.

10) Imaizumi M, Takeda M, Fushiki T (2000)Effects of oil intake in the conditioned place preference test in mice. Brain Res 870: 150-6.

11) American Institute of Nutrition (1993) AIN-93 purified diets for laboratory rodents: final report of the American Institute of Nutrition ad hoc writing committee on the reformation of the AIN76A rodent diet. J Nutr 123: 1939-51.

12) Folch J, Lees M, Sloane-Stanley GH (1957) A simple method for isolation and purification of total lipids from animal tissues. $J$ Biol Chem 226: 497-509.

13）香川靖雄，野澤義則（2003）図説医化学：chap. 3 糖 質代謝, p. 124. 南山堂, 東京.

14) Umegaki K, Ikegami S, Ichikawa T (1995) Fish oil enhances pentachlorobenzene metabolism and reduced its accumulation in rats. $J$ Nutr 125: 147-53.

15) Berry EM, Hirsch J, McNamara DJ, Thorton J (1986) The relation of dietary fat to plasma lipid levels as studied by factor analysis of adipose tissue fatty acid composition in a free living population of middle aged American men. Am J Clin Nutr 44: 220-31.

16) Shimomura Y, Tamura T, Suzuki M (1990) Less body fat accumulation in rats fed a safflower oil diet than in rats fed a beef tallow diet. J Nutr 120: 1291-6.

17）香川靖雄，野澤義則（2003）図説医化学：chap. 4 脂 質代謝, p. 140-4. 南山堂, 東京.

18) Iritani N (1992) A review. Nutritional and hor- monal regulation of lipogenic enzyme expression in rat liver. Eur J Biochem 205: 433-42.

19) Towle HC, Kaytor EN, Shih H-M (1997) Regulation of the expression of lipogenic enzyme gene by carbohydrate. Annu Rev Nutr 17: 405-33.

20) Jump DB, Clarke SD (1999) Regulation of gene expression by dietary fat. Annu Rev Nutr 19: 63-9.

21) Clarke SD, Jump DB (1997) Polyunsaturated fatty acids regulate lipogenic and peroxisomal gene expression by independent mechanisms. Prostaglandins. Leukot Essent Fatty Acids 57: 659.

22) Kim HJ, Takahashi M, Ezaki O (1999) Fish oil feeding decreases mature sterol regulatory element-binding protein 1 (SREBP-1) by downregulation of SPEBP-1c mRNA in mouse liver. A possible mechanism for down-regulation of lipogenic enzyme mRNAs. J Biol Chem 274: 25892-8.

23) Xu J, Nakamura MT, Cho HP, Clarke SD (1999) Sterol regulatory element binding protein-1 expression is suppressed by dietary polyunsaturated fatty acids. A mechanism of the coordinate suppression of lipogenic genes by polyunsaturated fats. J Biol Chem 274: 23577-83.

24) Rolls BJ, Castellanos VH, Halford JC (1998) Volume of food consumed affects satiety in men. Am J Clin Nutr 67: 1170-7.

25) Miller DL (1998) Effect of fat-free potato chips with and without nutrition labels on fat and energy intakes. Am J Clin Nutr 68: 282-90.

26) Shah M, McGovem P, French S, Baxter J (1994) Comparison of a low-fat diet, ad libitum complexcarbohydrate diet with a low-energy diet in moderately obese women. Am J Clin Nutr 59: 980-4. 


\title{
Original
}

\author{
Effect of a Lard Diet and Fish Oil Diet during the Growth Period \\ on Preferential Fat Intake in Adult Rats \\ Yoko Nakashima, ${ }^{* 1}$ Meiko Yokoyama, ${ }^{1}$ Takako Kodo, ${ }^{1}$ \\ and Atsuyo Shimoda ${ }^{1}$
}

(Received August 1, 2006; Accepted November 20, 2006)

\begin{abstract}
Summary: This study was conducted to clarify whether preferential fish intake by young adult rats could be linked to fat-feeding during the growth period using a high-fat lard diet (lard HFD) and a high-fat fish oil diet (fish oil HFD) with cellulose added to maintain the same energy concentration as a low-fat diet (LFD). Three groups of 4-week-old male Fischer 344 rats were fed either LFD (LFD group), lard HFD (lard HFD group) or fish oil HFD (fish oil HFD group). After 8 weeks, the LFD, lard HFD and fish oil HFD groups were further divided into 3, 2 and 2 subgroups, respectively, and each subgroup was sacrificed. Blood and liver samples were taken for analysis of lipids. One of the LFD groups and lard HFD groups were placed on a self-selection regimen of LFD and lard HFD, and the other LFD group and fish oil HFD group were placed on a self-selection regimen of LFD and fish oil HFD for 3 weeks. No significant difference in calorie intake or body weight was observed among the groups throughout the experimental period. The ratio of fish oil HFD intake/total dietary intake for rats fed LFD and fish oil HFD was lower than that of lard HFD intake for rats fed LFD and lard HFD. These findings indicate that when rats are placed on a self-selection regimen of LFD and HFD, fish oil HFD has fewer food properties that are preferable to lard HFD.
\end{abstract}

Key words : preferential fish oil intake, fat self-selection, high-fat diet, fish oil diet

* Corresponding author (E-mail: yokon@seitoku.ac.jp)

${ }^{1}$ Department of Human Life and Culture, Seitoku University, 550 Iwase, Matsudo, Chiba 271-8555, Japan 